Article

\title{
Spiritual Warfare in Circulation
}

\author{
Kimberly Marshall ${ }^{1}$ and Andreana Prichard ${ }^{2, *}$ \\ 1 Department of Anthropology, University of Oklahoma, 455 W. Lindsey St., Norman, OK 73069, USA; \\ kjm@ou.edu \\ 2 Honors College, University of Oklahoma, 1300 Asp Ave., Norman, OK 73019, USA \\ * Correspondence: aprichard@ou.edu
}

Received: 29 May 2020; Accepted: 18 June 2020; Published: 2 July 2020

check for updates

\begin{abstract}
Without a doubt, an overenthusiastic focus on rupture, as a way of coping with neoliberal trauma, has shaped the conversation about recent religious change in Africa. Yet, rupture remains at the heart of what African charismatics understand themselves to be doing. In this paper, we attempt to nuance this conversation about rupture in religious change in Africa by discussing that various ontologies of spiritual warfare are encountered, made legible, reframed, and redeployed, through direct interactions between Africans and Americans in the context of missionization. We illustrate the patterns of these reciprocal flows through two case studies drawn from our larger research projects. One study illustrates the case of Matthew Durham, a young American missionary who, when accused of sexually assaulting children at an orphanage in Kenya, adopted the spiritual counsel of a Kenyan missionary that the reason he had no memory of the attacks was because of his possession by a demon. Another study discusses the example of a Navajo pastor who applied charismatic techniques of spiritual warfare when under metaphysical threat during a mission trip to Benin, but simultaneously focused on building ontologically protective social networks with Africans. Americans and Africans involved in the flows of global Pentecostalism are equally sympathetic to charismatic renewal. However, the reality of threats presented by malicious spiritual forces are echoed and amplified through concrete missionary networks that belie traditional North-South flows.
\end{abstract}

Keywords: Pentecostal/charismatic missionization; spiritual warfare; networks

\section{Introduction}

The threat of "Voodoo Spirits" is often deployed within American popular culture as a stereotype of African religions, reflecting both a deep misunderstanding of actual African religious worlds and a chasm of disconnection between African and Judeo-Christian ontologies that has allowed these stereotypes to spiral out of control. Yet, Christianity is changing, both in America and in Africa, with the meteoric rise of Pentecostal/charismatic Christianity. The contemporary structures of interaction have brought together ontologies of the beings who inhabit the invisible world around us and have "translated" (Meyer 1999) threatening non-human actors in their wake. Spiritual "warfare" has become the common vocabulary through which Pentecostal/charismatic Christian actors across both continents have begun to reorganize the vast differences between traditional ontologies of threats posed by non-human actors into a common vocabulary of threat and battle. Despite this, how this ontological circulation across continents happens on the ground is still somewhat opaque.

For instance, the argument that his accusers had practiced "some sort of pseudo-tribal psychological voodoo" on him was part of the defense counsel's arguments in the 2014 case of the United States of America vs. Matthew Lane Durham. Durham, a young American missionary from Edmond, Oklahoma, was on trial for suspicion of sexually assaulting children at an orphanage in Kenya. Durham claimed that he was possessed by a demon who made him variously commit or forget he had committed 
sexual assault against the children. Government prosecutors saw this claim as evidence of "irrational behavior" (Western District, Document 26, p. 9) ${ }^{1}$, arguing that he therefore was not competent to stand trial. The defense counsel, on the other hand, refused to rule out the possibility that demon actors may have affected Durham, implicitly arguing that (in Oklahoma, at least) an ontological view that admits the real threat of demons is not tantamount to insanity. What both sides missed is the way in which Durham's demon-filled ontologies were developed in his direct interactions with African charismatic Christianity (Doc 26, p. 5).

Voodoo was also on the lips of Wallace Begay, an independent Navajo pastor who is part of the Pentecostal/charismatic Oodlání (believers) movement among Native Americans in Southwestern USA. Through his networks of reciprocal contacts with other independent charismatic pastors (both Native and non-Native), Begay traveled to Benin, West Africa, for a short-term mission trip during February 2008. Through the meticulous recording of his thoughts in a daily audio journal, Begay reveals that his assumptions about the ontological threats posed by "voodoo priests" holding "voodoo fetishes" were paired with his equally strong assumptions about the prophylactic power of reciprocal relationships. With a detailed catalog of the bolo ties and other gifts that he bestows upon various "kings", Begay demonstrates a deeply Native American practice of establishing reciprocal relationships through material goods, reinforcing the networked nature of the Pentecostal/charismatic movement that has fueled its spread across both Africa and Native North America. The building of reciprocal relationships in Africa is ontologically significant because it also reveals a deeply Navajo strategy of promoting positive relationships in a chain that bridges human and non-human worlds, in order to protect against a supernatural threat.

In this article, we push the boundaries of analysis by focusing on ontologies of spiritual warfare as they are circulated within the network-based nature of contemporary global Pentecostalism. Through these two case studies- the Durham case and the case of a Navajo missionary pastor traveling in Benin-we explore several concrete instances of contact. Our analysis traces how these ontologies came into contact with one another and how they came to circulate in broader global flows. This approach to the study of spiritual warfare does several things: first, it situates spiritual warfare not just within local and localized contexts, but within the context of conversations between localities. Second, this approach allows us to see how mutually constitutive and reinforcing the local ontologies of spiritual warfare actually are, and to highlight the ways in which they are made legible in the context of global flows and networks. Third, this approach sidesteps the debate about rupture and continuity in the Pentecostal/charismatic literature, within which the prominence of demons and other malicious non-human actors is used by both sides: both as evidence of Christianity's localization and as evidence of Christianity's assimilative properties-depending on the theoretical preference of the author. Our approach privileges instead the value of interconnected networks as a motivating factor in peoples' decision to engage with spiritual warfare and in shaping how they understand it. Ultimately, we argue that this flow of spiritual warfare ideas and practice across linked networks has the potential to seriously challenge our long-held assumptions about the Christian mission, from North to South or from core to periphery.

\section{Spiritual Warfare}

Spiritual warfare is a collection of rituals, practices and discourses that aim to do battle with (typically) invisible supernatural threats. It is undergirded by an ontological orientation that sees nefarious non-human actors as able to "intervene" in the affairs of humans, and in spiritual warfare as the "Christian version" of taking a stand against those forces. ${ }^{2}$ According to the volume Pentecostalism and

1 United States of America, Plaintiff, v. Matthew Lane Durham, Defendant. Case No. M-14-271-STE, United States District Court for the Western District of Oklahoma. Hereafter (Western District ... ).

2 For more details on the development and spread of spiritual warfare theologies and approaches to missionization since the 1970s, see Ruth Marshall (2016, pp. 98-100). 
Witchcraft: Spiritual Warfare in Africa and Melanesia, while Pentecostal/charismatic Christianity has been adopted in a vast range of cultures around the globe, the handling of witchcraft and demons through processes of spiritual warfare may well be the "crux of Pentecostal universalism" (Rio et al. 2017, p. 8). In the contexts of recent Pentecostal/charismatic spread, spiritual warfare describes the ways in which converts combat the ontological threats posed by traditionally understood non-human actors (spirits/ancestors/witches), translating them into a generic category of "demonic" (Meyer 1999). ${ }^{3}$ Furthermore, participants in global Pentecostal/charismatic Christianity have circulated a common set of beliefs and practices for combating these demonic forces: a weaponized form of Christianity, typically a kind of focused and long-duration prayer (R. Marshall 2016).

As a conventional practice of engaging with the non-human realm, spiritual warfare can be deployed by Pentecostal/charismatic Christians in many contexts. According to ethnographers working within the anthropology of Christianity, spiritual warfare is deployed against the ills of modernity, such as when Guatemalan Pentecostals pray against drug trafficking ( $\mathrm{O}^{\prime}$ Neill 2015), or by Ghanaian Pentecostal immigrants against the territorial spirits of an amoral secular Europe (Krause 2015), or against the demonic potential of modern technologies like cell phones and the Internet (Pype 2017). However, this warfare can also be deployed against traditionally understood threats, such as witches, territorial spirits, and ancestral spirits. For example, Daswani describes a visiting Nigerian pastor who led a group of Pentecostal Ghanaians in prayer over handfuls of sand in order to "sever ties to their ancestral homelands" and defeat the "witchcraft spirits" of that land (Daswani 2013, p. 467). Aboriginal converts in Australia have adopted spiritual warfare techniques, in order to protect them from sacred landscapes which can no longer be harnessed for beneficent magic because of knowledge lost to settler colonialism, and have now become ontologically threatening (Ono 2012). Moreover, among Navajo Pentecostal converts in the US Southwest, spiritual warfare in the form of "shooting" invisible arrows is used to protect converts from traditional non-human threats like shape-changing witches called skinwalkers (Marshall 2016).

Understanding how spiritual warfare operates on the ground is important, we argue, because it remains primarily motivating for converts. The drive to protect the self and loved ones from unseen threats has been, and remains, one of the major motivations driving religious conversion and fueling the Pentecostal/charismatic movement over other (less spiritually-warfare inclined) forms of Christianity. Furthermore, when tactics of spiritual warfare are deployed against the non-human actors of traditional ontologies, the practice itself becomes relevant to discussions about the continued relevance of rupture as an analytical category for understanding the spread of global Pentecostalism.

\subsection{Spiritual Warfare in Continuity and Rupture}

Some of the literature on spiritual warfare has focused on the way in which spiritual warfare has been localized by Pentecostal/charismatic converts, arguing that even religious change as dramatic as that represented by Pentecostal/charismatic Christianity is fundamentally localized in practice (Amster 2009; Chua 2012). Some have emphasized the ease with which Pentecostal/charismatic Christianity becomes incorporated into the traditional threatening ontologies of the new contexts where

3 Historians of missionization in Africa have been critical of the terms "conversion" and "converts", arguing that issues such as translation, local epistemologies, and inherited beliefs about another world at the time of Africans' first encounters with Christian missionaries and ideologies mediated between missionary intention and African interpretation. Africans did not always (could not always) see Christianity as a discrete category of human activity and could therefore not "convert" to it, leaving something else behind. Instead, they drew on both Christian values and preexisting ideas without distinguishing between them and with no sense of contradiction (Landau 1999, 2000; Larson 1997; Comaroff and Comaroff 1991, 1997). The terms "convert" and "conversion" thus often appear in scare quotes to signal this ideological critique. Scare quotes have not been employed here because the actors below practiced Christianity before they employed tools of $\mathrm{P} / \mathrm{c}$ Christianity or came to identify as Pentecostal/charismatic Christians and are assumed to have generally understood Christianity and/or religion as a discrete sphere of human activity that one could convert to or from in the conventional sense. The contemporary missions with which this article is concerned don't generally see themselves as converting the "heathen" or "untouched" to Christianity, but with converting already-practicing Christians to a new form of practice. 
it is adopted (Bastian 1993; Manning 1980). Therefore, they maintain, spiritual warfare represents, at its core, a type of continuity. This line of argument has been taken up by respected historians of Pentecostalism, especially in regard to Africa, arguing that many of the worship styles of Pentecostalism have African roots (Hollenweger 1997), with others taking a troubling stance that Pentecostalism better connects to a kind of "primal spirituality" that is apparent in less-modern cultures (Cox 1995).

Although distancing themselves from the colonialist implications of these lines of argument about why Pentecostal/charismatic Christianity has localized so easily in the global south, anthropologists have remained fond of continuity as a framework for explaining the movement's global spread. As scholars who tend to focus on the staying power of culture as a fundamental interpretive framework, not unimportantly because it foregrounds the agency of converts, the overlay of local meanings about spiritual warfare seems a particularly appealing way to explain what diverse cultures have "done with" Christianity. Insightful in-depth studies of local contexts of conversion have focused on explaining the ways that globally circulating discourses of spiritual warfare are localized and contextualized within culturally specific frameworks. Chua, for example, analyzes the continuity of adat gawai rituals in Malaysia (Chua 2012, p. 521). Stritecky (2001) focuses on the way spiritual warfare is localized in the Solomon Islands, and Jorgensen (2014) argues that spiritual warfare is practiced in Papua New Guinea, as a way of claiming enfranchisement into uranium gas development. Kiernan (1992) argued that Zulu Zionist churches in South Africa are largely adopting the practices and authority of non-Christian Zulu diviners, and Laugrand and Oosten (2010) have argued a similar continuity between Inuit Shamans and Pentecostal Inuit preachers. Authors in this vein argue that spiritual warfare is a Pentecostal/charismatic practice so malleable that it can be localized within drastically different cultural contexts.

The analysis of the localization of spiritual warfare, however, can also overstate the case for continuity. As José Casanova pointed out nearly two decades ago, Pentecostal/charismatic Christianity is "an uprooted local culture engaged in spiritual warfare with its own roots ... " (Casanova 2001, pp. 437-38), and that our focus on the localization of spiritual warfare may take our focus away from the projects of change that converts intend. As a leading anthropologist of Christianity, Joel Robbins has stated that these "perils" of "continuity thinking" may conflict with the reality of communities who openly declare their intention to participate in projects of change (Robbins 2003).

Part of understanding the argument for the discontinuity of spiritual warfare is in recognizing the fundamental translations of demonic power that are taking place in Pentecostal/charismatic contexts. These communities aren't just waging spiritual warfare against Christian demons, they are morally reframing the entire unseen universe (traditional and new, secular and sacred, physical and invisible) into blanket ontologies of good and evil. ${ }^{4}$ Post-colonial church missions became much more interested in incorporating existing religious ontologies in order to bring "the occult and evil within reach of church practices" (Rio et al. 2017, p. 13; See also R. Marshall 2016; Macdonald 2015). So, while Pentecostal/charismatic Christians may continue to recognize that traditional healers have power, they do not attempt to forge continuity with them (Casanova 2001). In fact, their dichotomized ontologies often group practices and non-human actors previously understood as positive (such as healers or ancestors) into the category of demonically powered. In Tanzania, for example, Lindhardt reports that the born-again population sees themselves as engaged in constant spiritual warfare against the forces of the devil, and "the players on the Devil's team include humans and spiritual beings associated with 'African tradition' such as witches, traditional healers ... and ancestral spirits as well as spirits associated with Islam" (Lindhardt 2015, p. 148). A similar eliding of traditionally understood

4 Some scholars, such as Peter Geschiere, have introduced the idea that the categories of non-human actors involved in spiritual warfare are themselves worthy of study, since many of them (including the concept of witchcraft and sorcery) are always translations of local notions, yet have often become appropriated by the local populations and translated into local terms (Geschiere 2017, p. 286). Marshall (2015) attempts something of this kind of translation exercise with Navajo non-human actors, as translated through Pentecostal Navajo discourse. 
non-human actors happens throughout the global Pentecostal world, including in the highlands of Bolivia (Harris 2006, p. 54) and among Navajos in Native North America (Marshall 2016). According to these authors, while a cosmological universe containing many kinds of enlivened non-human actors may remain stable through Pentecostal/charismatic transformation, the practices of interacting with them (such as spiritual warfare) certainly represent rupture.

So vexed has this debate between continuity and rupture become that it comprises what several scholars have called the central theme of the anthropology of Christianity (Lampe 2010; Coleman and Hackett 2015, pp. 14-16), and discussing the nuances of the completeness of the "break with the past" (Meyer 1999) has become key to leading contemporary studies within the anthropology of Christianity (Engelke 2010). In trying to understand how the practice of spiritual warfare itself shapes the cosmological imaginary of the contemporary Pentecostal/charismatic movement, some scholars have discussed the ethical frameworks involved (Daswani 2013) or the time/space assumptions implicit (R. Marshall 2009). Others have discussed the way that a focus on language and expressive culture can mediate these inherent contradictions (Meyer 2004; Engelke 2010; Marshall 2016). In this article, we attempt to write our way out of this debate between continuity and rupture, by focusing on the networked circulation of spiritual warfare.

\subsection{Spiritual Warfare in Circulation}

Scholars have long recognized the egalitarian structure of Pentecostal/charismatic networks. Largely, this analysis has been focused on the utility of the network structure for evangelization. Within Pentecostal/charismatic Christianity, the fact that recent converts are quickly transformed into Evangelists themselves has been widely cited as one major factor explaining the movement's rapid spread (Annis 1987; Blumhofer 1993; Bowen 1996; Chesnut 1997; Kamsteeg 1998; Lehmann 2001; Synan 1997; Stoll 1990; Martin 1990). Incorporated into this analysis has been a focus on media and the ways in which media production and circulation is used to unify Pentecostal/charismatic believers across the globe. Coleman (2000) and Hackett (1998), in particular, have conducted in-depth studies of the media products and language ideologies in circulation along Pentecostal/charismatic networks. The way that the interconnected media networks affect the musical landscapes of global Pentecostalism has been another focus for many scholars (Ingalls and Yong 2015; Butler 2019). Some have studied the political implications of these interconnected networks for statehood, in places like Nigeria (R. Marshall 2009; Obadare 2018), Brazil (Helgen 2020) and Guatemala (Garrard-Burnett 1998). A close attention to Pentecostal/charismatic networks, and the people that move along them, is fundamental to understanding the contemporary global Pentecostal/charismatic movement. From a theological perspective, the relationality of the Pentecostal/charismatic movement can be overlooked, because scholars and theologians understand it as continuing along the fundamental individually-centered Protestant salvationist theological logics of rational Protestantism. ${ }^{5}$ Yet, as Robbins summarizes, " $\mathrm{P} / \mathrm{c}$ Christians are a far-flung network of people held together by their publications and other media productions, conferences, revival meetings, and constant travel" (Robbins 2004, p. 125). ${ }^{6}$ We maintain that the role of these interconnected networks in circulating ontologies like spiritual warfare has been largely overlooked. ${ }^{7}$

5 A noted exception is Omri Elisha's work on the importance of relationality in Evangelical bible study groups in Tennessee (Elisha 2015).

6 In this, networks of $\mathrm{P} / \mathrm{c}$ Christians resemble pre- and early-colonial religious, spiritual, and clan-based networks spanning the African continent and, later, the diaspora. Drawing on Neil Kodesh's work about "therapeutic networks" between discontiguous clan lands, Prichard makes a similar case for the networks of affective spirituality that knit together a religious community in eastern Africa in the latter half of the nineteenth century (Kodesh 2008; Prichard 2017).

7 Ruth Marshall (2016) has gestured toward the importance of the circulation of these ontologies. She says, "The complex processes of globalization at work in the elaboration and circulation of this fairly heterodox interpretation of apostolic spiritual warfare provides a fascinating insight into the dynamic and almost haphazard way in which charismatic Christianity grows and spread. Rather than a specific doctrine or doctrines, one finds a bricolage, a living, moving corpus of ideas, scriptural interpretations, images, discourses and techniques developed and circulating across a range of personal, institutional 
In this article, we push the boundaries of analysis by interpreting Pentecostal/charismatic spiritual warfare practices through the network-based nature of contemporary global Pentecostalism. We explore specific instances of culture contact between various iterations of spiritual warfare discourses. The first is a case which links Kenya and Oklahoma in 2014; the second case links Benin and the Navajo Nation in 2008. These examples illustrate that, while ontologies of spiritual warfare produce rupture at the local level, these discourses can only truly be understood when contextualized as global flows along Pentecostal/charismatic networks. And, to be sure, these examples can also be seen as in the tradition of much longer-standing networks, those of trans-Atlantic creativity, exchange, change, improvisation, and violence that date back to the early days of the slave trade (Thornton 1998; Matory 2005; Miller 2012; Sweet 2011). Yet, they are also equally part of new global flows, those of Pentecostal/charismatic Christianity that connect South America, Africa, and Oceania in unique ways.

\section{Matthew Durham's Demon}

On 13 June 2014, Kenyan staff at the Upendo Children's Home in peri-urban Nairobi accused one of the American missionaries serving at the center of sexually assaulting children under his care. Matthew Lane Durham, then nineteen years of age, was, at the time of the accusations, on his fourth short-term mission trip with the faith-based NGO Upendo Kids International. The NGO is based in the Oklahoma City commuter suburb of Edmond, but serves orphans and other vulnerable children in the founder's hometown of Juja, Kenya. Initially, Durham strenuously denied all charges of wrongdoing. He protested that he could not recall even a single incident that might possibly have been construed as inappropriate, much less as sexual molestation. Trying to sort through the morass, Eunice Menja, the mission's founder, made a suggestion: while Menja did not believe Durham himself "would have ever been capable of hurting the children", she did think that he might "have been possessed by an evil spirit or demon" that caused him to molest them. Possession, she told Durham, would explain why he could not "remember his acts" (Western District, Document 71; Western District, Document 63, p. 7).

In the hours and days after staffers made the first round of accusations against Durham, the young man himself adopted Menja's explanation of the events: that he had been possessed by a demon who had made him commit illicit sexual acts against children, and then forget them. While still in Kenya, Durham began to seek out ways to have the demon exorcised. Namely, he reached out to his friend and fellow missionary, Hannah Nichols. Durham once described Nichols, who had previously spent time at Upendo but who was not on this particular trip, as "very spiritual"; she "believed in demons, speaking in tongues, prophesying" (Western District, Document 473-73, p. 151). He believed that he would find in Nichols a sympathetic ear and sent her a text message explaining his predicament. He wrote (with an informality not uncommon in a text exchange): "please the moment I get back take me to your pastor in Norman ... I do have a demon", he said, "I'm beyond miserable. I've never been so close to losing my mind. ... Can your pastor help me?" Hannah responded: " ... you should talk to him about it and he'll have insight for you for sure!" When pressed as to whether Chris Bennett, the pastor at Antioch Community Church in Norman, OK, could "get rid of" the demon, Nichols responded: "idk Matt he doesn't tell us about the demons that he gets rid of every week ... but I want you to come and see anyway. Even if you just get prayer there's no harm in that" (Western District, Document 70-79, pp. 5-6). ${ }^{8}$

and virtual networks and engendering an elastic, undisciplined and pragmatic process of inspired creations, borrowings, combinations and adaptations" (R. Marshall 2016, p. 97).

8 Antioch Community Church is an independent, non-denominational evangelical church in Norman, Oklahoma. (Norman is another Oklahoma City suburb located about thirty miles south of Edmond.) Missionaries from the Antioch International Movement of Churches (AIM) and Antioch Ministries International, based in Waco, TX, planted Antioch Norman in 2009. AIM and the Antioch movement are classified as "Baptist-Charismatics". While not all southern Baptists accept the role of charismata in everyday life, there are an increasing number who do. For example, after a decade-long resistance, the Southern Baptist Convention relented, and in May 2015 they agreed to admit missionary candidates who speak in 
The urge by Durham and his Kenyan and American colleagues to turn toward spiritual warfare as a way to understand and adjudicate accusations of sexual assault is a fascinating episode in its own right. Indeed, media in Oklahoma and in Kenya, and the attorneys on the case were captivated, making much of the episode as an "illogical" sideshow, a distraction, to an otherwise serious matter. As a scholar of missionization and Africans' adoption and adaptation of Christianity in East Africa, Prichard had been working on these networks for a related scholarly project. Thus, she saw the actors' engagement with ontologies of spiritual warfare as something more than "evidence of [Durham's] irrational behavior" or as "some sort of pseudo-tribal psychological voodoo" (Doc 26, p. 5). ${ }^{9}$ Rather, Prichard noted that the discourse of spiritual warfare at play in the Durham case did not move North-South or South-North exclusively. The missionaries' understandings and invocations of spiritual warfare circulated on a complex playing field, building on and reinforcing one another as they moved along interconnected social networks. Indeed, Durham and his fellow missionaries' engagement with spiritual warfare-precisely, with a demon named "Luke" - provides clear data on the way that spiritual warfare circulates through concrete interactions within global and transnational Pentecostal/charismatic networks. Specifically, it illustrates the role that individual interactions play in shaping and reinforcing the ontologies of spiritual warfare that circulate in particular networks.

It did not take long after Menja suggested that Durham might be possessed that he fully committed to the idea of a demon controlling his actions in Kenya. ${ }^{10}$ He named his inner demon "Luke", and read Luke's control over him back onto the days and nights before the alleged assaults occurred. Durham confessed in a separate text exchange that he "cannot control himself" against Luke's wishes and that he is "powerless against his urges" (Western District, Document 15). Luke, he wrote (again with characteristic informality), "takes me at night and i am powerless over what luke wants. Yes i named him I know how crazy that is. He whispers in my ear all day and hes so hard to resist. ... Literally he takes me at night and there is nothing I can do to stop him. Im asleep, what can i do?" Durham concluded by admitting, "You honestly have no idea ... i've prayed so much, but every night luke gets what luke wants" (Western District, Document 15).

Durham's defense counsel used a series of legal filings in an attempt to explain away Luke's presence in Durham's life. In a motion to suppress essentially all verbal, written, and electronic exchanges that Durham made while in Kenya, his attorney Stephen Jones argued that "as a result of Mr. Durham's confinement, illness, and dehydration, as well as the psychological manipulation, lies by Ms. Menja, and isolation from other volunteers", Durham "became convinced" that he had a demon within him. He was "faced with a persuaded "truth" that he committed the acts as alleged", yet he argued, Durham had no recollection of committing those acts. "Taken in conjunction with his religious beliefs, relative isolation, foreign environment, and an accusatory environment ranging from aggressive to confessional in nature", Durham "internalized and accepted the explanation of his captor" (Western District, Document 63).

Durham's attorney described his client's invocation of a demon as a consequence of him being an impressionable young man coerced by a trusted elder into believing that he had a demon. His belief in Luke was, in this reading, an illogical response to stress and to Menja's power of suggestion. Indeed, Jones argued in another motion that Durham's statements were illogical and constituted "evidence of irrational behavior" (Doc 26, p. 9). Government prosecutors, for their part, argued similarly that they

tongues. This move by the Convention was part of a trend of normalizing members who embrace the "gifts" of the holy spirit. (Religion News Service)

9 In a formal statement to media, Defense counsel Stephen Jones argued that "The events that occurred in Kenya the last maybe five six days that Matt was there frankly reveal some sort of pseudo-tribal psychological voodoo practiced on him". The Oklahoman, 22 July 2014, Matt Dinger "Edmond man faces charges of sex acts with Kenyan children", accessed 3 March 2020.

10 On 13 June 2014, Eunice Menja suggested to Durham that he might have been possessed by a demon. On 15 June 2014-less than two full days later-Durham seems to have adopted this explanation and began to act upon it (Western District, Document 15). 
believed Durham's "sincerely believed delusions" were indicative of a mental health issue and that he was therefore incompetent to stand trial (Doc 26, p. 5).

Although Jones granted Durham's "religious beliefs" some explanatory power in the role Luke played in Durham's alleged transgressions, the unique internal logic of the international networks in which Durham and his fellow missionaries were embedded was nearly completely lost on Jones and his colleagues on the prosecution team. Indeed, there are several factors that made an attack by a non-human actor appear as a viable possibility in the minds of Durham and the rest of the Upendo contingent. The first is the relationship that Durham and his fellow American missionaries had with Eunice Menja, the founder of Upendo. Menja, a Kenyan by birth, founded Upendo in Edmond, Oklahoma, where she and her husband had been living and working for over a decade. Beloved by many, Menja loomed large in the lives and spiritual imaginations of many of Upendo's high-school aged American missionary volunteers. Durham and Menja were particularly close; she often referred to him as her son and he "trusted her to near devotion" (Western District, Document 63, p. 8). Menja has bachelor's and master's degrees in Human Development and Family Science from Oklahoma State University, and has worked as an adjunct professor of psychology at two universities in the state. Furthermore, she was a deeply religious woman; witnesses testified that Menja "openly believes in evil spirits" and that she "openly encourages certain Upendo volunteers to speak in tongues" (Western District, Document 63, p. 7). Given these credentials, her near-celebrity status in the small evangelical community of Edmond, and her close relationship with Durham, the young man had a habit of turning to her for "psychological expertise, personal confidence, and spiritual guidance" (Western District, Document 63, p. 21). It is no wonder, then, that Menja's suggestion that Durham was possessed resonated with him.

\section{Non-Denominational Networks of Possession}

There is a second, and more significant, factor that made an attack by a non-human actor (such as the demon Durham named "Luke") a viable possibility to Menja, Durham, and their American colleagues. They, as well as many Kenyan Upendo staffers, are all involved in the same reciprocal networks along which these ontologies circulate. In Juja, the Menjas and Upendo are affiliated with the Presbyterian Church of East Africa (PCEA). While one might not regularly see charismatic expressions in the United States, Presbyterians and others within mainline Protestant churches in Kenya are widely accepting of spirit Christianity. This, historians of religion in Africa make clear, is not the same sort of spirit Christianity often associated with the "traditional spirit world of Africa", but it is something new, coming in part from missionary Christianity and in part from the more recent Pentecostal/charismatic renewal of Christianity on the continent (Gifford 2009, pp. 202-3). As Paul Gifford and others argue, the idea of a spiritual cause of evil has come to characterize the PCEA as an institution: "The PCEA is currently promoting a spirit Christianity which takes it far from Presbyterianism in the West", toward "'a general Pentecostalism' that is as North American as it is African" (Gifford 2009, p. 249). Among Kenyans sympathetic to a spirit-filled Christianity, there is widespread acceptance of the link between possession by demons or other evil spirits and "antisocial activities", including homosexuality and child abuse. Moreover, as we have seen, Durham and other among Upendo's American volunteers embraced strands within contemporary Bible Belt non-denominational Christianity, that understood non-human actors to act in the realm of the real-ideas at the root of Durham's text request for an exorcism at Antioch Norman.

What is significant here is that Durham's attack by a non-human actor was not something that the Upendo staffers or American volunteers believed they could remedy within the formal networks in which they operated-either judicial or denominational. Indeed, due to the fact that Durham's alleged transgressions were considered to be the fault of a non-human actor, redress in the courts-either Kenyan or American - was not a possibility. Indeed, Upendo staffers avoided reporting the abuse to authorities in Thika for six days after the allegations were first launched. Durham might have escaped prosecution entirely if it were not for a single missionary who brought the allegations to the attention 
of the United States authorities, who eventually charged him under a 2003 federal law known as the Prosecutorial Remedies and Other Tools to end the Exploitation of Children Today (PROTECT) Act.

What is perhaps more significant than the lack of judicial remedies is that Durham, Menja, and others privy to this non-human attack against Durham at Upendo implicitly agreed that they could not tap into their extant denominational networks to find advice or a remedy for the young man's alleged abuse. Durham, for example, did not seek advice from his pastor at the non-denominational, evangelical Edmond Church of Christ. Nor, for that matter, did he willingly consult the "religious counselor" from whom his father insisted he seek therapy. ${ }^{11}$ Eunice Menja did not call on her pastors at the First Presbyterian Church in Edmond (FPCE).$^{12}$ None of the actors sought counsel from pastors at the PCEA in Juja Township, working instead to hide the allegations from its membership for fear of vigilante justice or other physical retribution (Western District, Document 19, p. 33). No one sought to forge continuities with traditional healers or ancestors, either (Casanova 2001). Rather, they avoided resources with official claims to religious authority in the denominational networks in which they operated, and opted instead for an exorcism at an unaffiliated, non-denominational church in Norman, Oklahoma.

This fragmentation of the denominational networks highlights a significant common ground among people involved in a very localized experience of international missionization-that is, the resonance of spiritual warfare outside of denominationally-controlled channels. As we have seen above with historical cases on the continent, this "far-flung network of people" played a vital role in circulating the ontologies of spiritual warfare (Robbins 2004, p. 125). Indeed, in the days and weeks that followed Josephine Wambugu's first round of allegations against Matthew Durham, the rhetoric of spiritual warfare moved in ways generally overlooked in the scholarly literature. It flowed not North-South, or even South-North, but along pathways that were circular in nature and mutually reinforcing in practice. Ideas that were presented to Durham by an expatriate Kenyan, living in Oklahoma but working periodically in Kenya, were recirculated in Oklahoma when Durham called on Nichols to help him access an exorcism. They gained even more traction when deployed in the United States federal court, by attorneys who may have doubted their veracity but who counted on them to resonate with jurors hearing the case. Moreover, resonate they did: the case was eventually decided against Durham. Having been found guilty on four counts under the PROTECT Act, Matthew Durham is currently serving a forty-year sentence in the United States Penitentiary in Marion, IL. In 2020, he will be twenty-five. He will never be eligible for parole.

\section{Pastor Begay's Bolo Ties}

And one of the beaded bolo ties that I had, and I presented it to the king of the South. And ... he had a very, very good spirit too. That king. He was very gentle, very nice, very friendly. And, uh, so ... I gave him a bolo tie and he said that he would make an announcement in front of everybody that he would receive that on behalf of all the Southern kings. (Begay Journal $2 / 24 / 2008)$

11 Biblical counseling, or 'nouthetics', is a reformed/fundamentalist movement, a form of Christian therapy which rejects conventional approaches to mental health care in favor of the Bible as sufficient, superior, and more authoritative than psychological science, theory, or technique (Weaver 2011). Biblical, pastoral, Christian, and faith-based counselors seek to reclaim the role of counseling within the church itself (McMinn et al. 2010). Psychological conditions or distress is best treated, many Evangelical Christians believe, with prayer, confession, and repentance rather than the "permissive and guilt-absolving premises of psychology" (Joyce 2017). "Nouthetic" or "biblical counseling" is seen by many Neo-Evangelicals, fundamentalists, and Reformed Protestants as a preferred alternative to deliverance from sin through exorcism (Weaver 2011).

12 FPCE is not a mainline Presbyterian church, but is a partner congregation in a new Presbyterian denomination, ECO. The acronym refers to the denomination's three-fold commitment to: evangelism (make disciples of Jesus Christ); covenant (connecting leaders through accountable biblical relationships founded in God's grace); and order (a commitment to a shared way of life together) (FPCEdmond.org, 2019). Churches within the ECO denomination tend to be more conservative than other Presbyterian denominations (such as the Presbyterian Church USA), and in fact, the denomination splintered from the PC(USA) in 2012, when the PC(USA) General Assembly voted to ordain partnered LGBT clergy. 
On 23 February 2008, Pastor Wallace Begay (Navajo) found himself in the middle of a "King's Peace Meal" in the interior town of Save in Benin, West Africa. Born and raised on the rural Navajo Reservation in the Southwestern United States, prior to this trip, Begay's only experiences away from home had been revival meetings on other Native American reservations in Montana and Arizona. ${ }^{13}$ None of that had prepared him in the least for the sights, smells, and extreme disorientation he experienced in his quick one-week mission trip to West Africa. Moreover, yet, despite his major cultural disorientation, Begay's ontological compass remained steady, as his frameworks for encountering the non-human world circulated across the same networks that brought him to Africa in the first place.

Pastor Begay is the Navajo pastor of a small, independent Pentecostal church located near the reservation town of Shiprock, New Mexico. His church is part of the widespread Oodlání (believers) movement, active across the Navajo Nation, with strong connections to Pentecostal/charismatic Christianity, as practiced across Native North America and globally (Marshall 2016). Pentecostal/charismatic Christianity among Navajos has grown in appeal by empowering Navajo-led ministers like Pastor Begay, who preach, sing, and practice faith healing in the Navajo language, but without compromising the bedrock neo-Pentecostal principle of the demonic nature of Traditional Navajo religion (Marshall 2015).

Marshall became familiar with Begay during extended fieldwork for her book Upward, Not Sunwise (2016) and he became one of her main consultants for that book. While conducting fieldwork for that book, Marshall was contacted one day by Pastor Begay. He had been invited, through his networks of Native North American evangelists, to accompany a mission trip to Benin. If he could get himself to New York City, they would take him the rest of the way. Pastor Wallace put Marshall to work, researching information about Benin for him, so that he could visit family, friends, and other churches on the Navajo Nation, in order to raise funds to get to New York. Marshall also assisted Begay in getting his passport, researching the necessary travel vaccinations and where to acquire them, and booking a plane ticket to and from New York City. In exchange, Pastor Begay agreed to take a mini cassette recorder with him, in order to keep a daily journal on his activities. Marshall attached a list of questions to the recorder for Begay to consider in his journal, including practical questions like "Where did you go today? What did you do? Who did you talk to? What did you eat?" as well as more reflective questions like, "What did you think about today's events? What surprised you today? What seemed normal today?" Pastor Begay was compensated for his journaling as a research assistant and received a copy of the transcribed journal.

As a first-person depiction of a Navajo man first encountering Africa, Pastor Begay's field journal is an interesting ethnographic artifact in its own right. However, for the purposes of this paper, it provides crucial information on the praxis of spiritual warfare circulation through Pentecostal/charismatic networks. In the first place, it is hard to overstate the degree of culture shock Pastor Begay was experiencing during his short trip to Benin. Without even mentioning his first experience with jet lag or malaria medication, the journal transcript reveals just how disoriented Begay was, and how aware he was of that disorientation. In one passage, he describes a trip to the marketplace (with a guide):

Well we went to the marketplace and it reminded me of Shiprock Fair with all the people. The dust. Traffic. The trash ... but this was like ... [laughs] a hundred times worse. And the smell and the dust.... it was terrible. Really. There was just heaps and heaps of trash. It was like people trying to sell this and that. Anything, I guess, to make some money ... it was quite a shock. (Begay Journal 2/20/2008)

Begay was also horrified by the poverty he observed, saying, "The livin' conditions here and it seems like throughout the whole of Africa it's just very poor. Moreover, people are very, very poor". Cultural differences also upset him. He was disturbed by street food, commenting, "They were selling

13 He had also once traveled to a Bible conference in Missouri. 
some kind of ... I don't know if it's a rat, whatever, on a stick ... they fan it out- arms and legs stretched out and hanging on a long pole an then they wave it alongside the road for people to buy ... roasted boa constrictor [makes grossed out noise]" (Begay Journal 2/24/2008). He was also unsettled by other aspects of everyday life in Benin, including the driving etiquette and by the generators constantly flickering the electricity. He was particularly disturbed by the smells he encountered. He says:

Oh my God. The smell is just horrific. I mean, you would not believe the smell. You know, I mean it's just ... whew! And people don't ... you know, have a public bathroom or a public restroom. It's like they just pee wherever .... And it's not against the law or anything. It's just, you know, you gotta go, you just stand there and just ... let it go! [laughs]. (Begay Journal 2/24/2008)

Moreover, in his record of what he was eating, he seems to have survived on French fries for the entire week of his visit (despite his repeated declarations that he was willing to try frog legs). "It's just", he says, "I didn't trust their chicken" (Begay Journal 2/24/2008).

The journals also reflect Begay's own awareness of his disorientation. On the first full day in Ouidah (a coastal town in Benin), Begay accompanied the mission team on a visit to a local "King". His reflection on his own culture shock is astute, even naming it as such. He said:

Well ... today we went over to one of the King's ... uh, palace. And we were greeted. Um, we were welcomed to the palace. We were greeted by drums and singing ... beautiful voices. We went inside ... it was scary at first. I was knock[ing] ... my knees were knocking. [Laughs]. I was scared, like. I didn't know what to expect. Like, you know, they didn't tell me what to expect, or not to be afraid, whatever. But ... to me it was sort of scary. Culture shock, is what it is, I guess. (Begay Journal 2/22/2008)

Without a doubt, Pastor Wallace Begay encountered Benin through a lens of shock.

Yet, in spite of his admitted culture shock, Begay easily assimilated ontological threats into a familiar worldview and dealt with them in recognizably Pentecostal/charismatic ways. The second "king" they visited in Ouidah was more "traditional". While Begay had been able to get over the shock of the African drumming that greeted them at the first king's palace (even eventually joining in the dancing), he interpreted the drumming at the palace of the second king as significantly more threatening. Begay notes that this king was holding "voodoo fetishes" and was accompanied by "voodoo priests". As they entered, they "went in with a lot of drumming, lot of singing, the same way. But the atmosphere in that place was different. Uh, [it] had a different atmosphere. Had a lot of spiritual warfare on our part, uh when we went into that place, in his palace" (Begay Journal 2/24/2008). In this passage, Begay is recognizing traditional symbols of spiritual power, transliterating them as demonic, and describing concrete actions he took in order to protect himself from ontological threat. These are the same concrete actions he had used in the past to protect himself and his mother from the supernatural attacks of Navajo skinwalkers (Marshall 2016).

In another part of the journal, he describes coming under supernatural attack early in the morning of 23 February. That day, the party had traveled from the coastal town of Ouidah to the interior town of Save. The motel in which they lodged that night was significantly sparser than their lodgings in Ouidah, so it is entirely likely that Begay (still only in his third day in the country) was feeling unsettled to begin with. In any case, in the journal, Begay reports that he woke up around midnight. He heard what sounded like pebbles being thrown at his door. He interpreted this sound as an agentive action-as either a human or non-human actor deliberately attacking the party. "Someone was throwing pebbles at our door", he says. His response is to engage in the attack, supernaturally. He says:

And so, I went and I got my prayer shawl out, and I just wrapped it around myself. I just got up and ... got up and started to pray. The power of prayer ... I tell you ... you know. 
It shields you. I just prayed the blood [of Jesus] ${ }^{14} \ldots$ I prayed for like three hours. And uh, didn't go to sleep until about 3 o'clock. (Begay Journal 2/24/2008)

Because of this active shielding through prayer, he reports that, unlike the rest of the party, he did not have any nightmares or stomach problems. In the journal, he directly attributes this outcome to his three hours of shielding prayer. Interestingly, however, even though prayer was shielding him, his watch stopped. Begay commented, "But they said that that's what happens when they get into voodoo ... witchcraft places, you know. That watches will stop working and all this crazy phenomenon will start happening" (Begay Journal 2/24/2008). So, even though Begay dismissed this inconvenience as a trivial matter, he still understood it to be supernaturally predicated.

There is nothing distinctively African or Navajo about the kind of spiritual warfare being waged here against the stopping of watches. Begay is clearly deploying spiritual warfare techniques (intensive long-duration prayer, using the "blood of Jesus" as a spiritually protective shield) that are widely disseminated across global Pentecostal/charismatic networks. There is nothing really that moves beyond even stereotypes of Africa in his description of the "voodoo priests" or witchcraft, since his interactions with actual Africans remained fairly superficial. While the guide offered to take them to "services" that were happening "all the way up and down the road" between Ouidah and Save, the exhausted party declined, missing the opportunity to learn about Benin Pentecostal/charismatic Christianity localization. However, what the Pastor Begay journal does contribute to our understanding of the actualization of spiritual warfare ontologies in circulation is the ontological value of those very circulations themselves. In encountering ontological threats in Africa, Pastor Begay not only engaged globalized rituals of spiritual warfare, he also attempted to neutralize ontological threats in a distinctively Navajo way: by building reciprocal relationships with powerful actors. He did this through bolo ties.

\section{Networks of Reciprocity}

One of the notable features of Pastor Begay's journals is the careful inventories he kept of what gifts he distributed, and to whom. For instance, in the visit to the "first king" in Ouidah, Pastor Begay recounts:

... When we were leaving, after I danced, gave his pastor a beautiful necklace, my turquoise choker. I wrapped it around her neck, and she also sang another song .... It was a really good spirit that was there. And I know that the Lord's gonna bless the first king, Amen. And uh ... we left there, and he wants to come to America. He wants to come to one of our revivals. (Begay Journal 2/24/2008)

In this passage, the giving of gifts is directly linked in Pastor Begay's stream of consciousness audio journaling, with reciprocal visiting. As discussed below, for him, the giving of gifts actualizes the building of relationships.

A few days later, the mission party was in the interior town of Save, attending a "King's Peace Meal" for local dignitaries. Begay's journal recounts in detail what was given and to whom, as in this passage: "I also gave two necklaces, a choker necklace to the king and I also gave a necklace to his wife" (Begay Journal 2/24/2008). Furthermore, included is his record of the gifts he received in exchange. "In return he gave us like strips of green and red ... um ... cloths. I guess you would call it. He gave those to us" (Begay Journal 2/24/2008). The most interesting gifting passage is the narrative of one bolo tie. During the ceremony, Pastor Begay reads a "good spirit" on one of the visiting kings in attendance.

14 This phrase, "Pray the Blood of Jesus", is a partial reference to a larger theological ideology in Pentecostal/charismatic circles that one can pray (or "plead") the blood of Jesus for protection. In this ideology, the "blood" is conceptualized as an invisible barrier that (because it is ontologically powered by the sacrifice of Jesus on the cross) is a strong shield against attack by demonic forces. In this transcript, note that Pastor Begay does not even finish the phrase. Within his circles, the same concept is signaled by the phrase "prayed the blood". 
Aware that gifting out of turn may cause jealousy and disruption, Begay asks the guide (Henry) if it would be permissible to give that king a bolo tie. After a bit of hesitation, Begay "got permission" to do so. He recounts that this king (whom he calls "the king of the South") has a large kingdom in the south and was so pleased with the gift of the bolo tie that others on the mission team noticed that he continued to wear it the next morning, even after he had removed all his other necklaces. As with before, the giving of this gift (recounted in detail in the journal) is paired with an invitation for further reciprocal relationships with the Southern King. "We talked with him and he gave us his cards. And he wants to invite us to come to his kingdom. Sometime ... But he wants to gather at least 25,000 people and he wants us to come and bring the peace meal to his kingdom also" (Begay Journal 2/24/2008).

Begay's gifting fits long-established techniques of fostering reciprocal relationships through the exchange of material goods, within both Native American and African communities. This reliance on fostering networked ties fits well within the decentralized structure of Pentecostal/charismatic Christianity. Moreover, as the literature above suggests, the network structure is very much part of how this movement has spread across the globe so quickly. However, from a Navajo perspective, facilitating reciprocal relationships through material goods is about more than fostering positive human relationships; it also has prophylactic ontological power. Networked social relations offer protection based on three axioms. First, from a traditional Navajo perspective, reciprocal relationships can be made with any actor, whether human or non-human. As Charlotte Frisbie explains, "The Navajo ceremonial system ... [is] based on a chain of reciprocity which stretches between the sacred and profane worlds and that includes everyone, from the Holy People and singers to the one-sung-over and students", Frisbie (1987, p. 89). ${ }^{15}$ Moreover, while recent Navajo (Diné) Studies scholars have emphasized the centrality of kinship ties $\left(k^{\prime} e ́\right)$ as the fundamental building block of Navajo social life, ${ }^{16}$ these ties extend into the non-human world as well. For instance, a traditional Navajo prayer may address the Holy People using the terminology for grandparent, placing the supplicant in the position of the grandchild. Because of the strong ethical obligation to care for weaker relatives, this phrasing of prayers is a way of influencing the actions of powerful non-human actors by invoking reciprocal kin obligations (Gill 1987, p. 118). So, reciprocal kinship ( $\left.k^{\prime} e ́\right)$ ties can link both human and non-human actors, and Pastor Begay was operating in a perfectly consistent manner with his Navajo upbringing in trying to build reciprocal ties with actors in Benin.

The second axiom that explains the protecting character of reciprocal networks is that material goods can cement and influence these reciprocal social ties. Again, according to Frisbie, in the Navajo ceremonial system, "one is required to make gifts or 'offerings' (yeel) to those whose services and assistance are desired. Once such gifts are accepted, the receiver is compelled to respond; the gifts simultaneously compel and insure the efficacy of the performance" Frisbie $(1987$, p. 89). Scholars have long noted that this use of material goods exchange to cement reciprocal ties between human actors is the same principle used to cement reciprocal ties across the human/non-human divide. As Reichard noted in 1949, offerings are made "in the spirit of barter", in order to establish reciprocal relations with deities and achieve a desired end (Reichard 1949, p. 68). As an example of this bartering attitude, Reichard provides a line from a traditional Navajo prayer: "I have made your offering to you/My mind restore for me" (Reichard 1949, p. 68). So, in carefully cataloguing his exchange with various actors in Benin, Pastor Begay wasn't just expressing his desire to make friends, he was also ontologically activating an alignment with what he likely saw as a cascading network of his interlocutor's social networks, both human and non-human. ${ }^{17}$

15 In Navajo Ceremonials, the "singer" is the healer (sometimes called the "medicine man"), and the "one-sung-over" is the patient. This is a direct translation of the Navajo word.

16 See, for instance, Lee (2014).

17 Begay's African interlocutors might also have been thinking about these as reciprocal exchanges capable of cementing and influencing social ties within the human, and across the human/non-human divide. Indeed, Africans across the continent have long imbued gifting and exchange with power beyond the economic, granting it moral, aesthetic, political, and symbolic power as well (Shipton 2007). Because of the value that unique individuals held in societies throughout precolonial Africa 
The importance of these materially activated social networks for our conversation about spiritual warfare is in the third axiom: that these networks can be ontologically shielding. In presenting the "King of the South" with a bolo tie, Pastor Wallace was both aligning himself with the spiritual family of the Southern King, and fundamentally obligating (though material exchange) their protection against "bad spirits" as well. In this way, he was using long-held Navajo techniques for controlling powerful (and therefore potentially dangerous) non-human interlocutors (Garrity 2000, p. 534).

In traditional Navajo ontological frameworks, the exchange of goods has the potential to bridge the human/non-human divide, and it is therefore one of the primary ways in which traditional Navajo ceremonialism aims to provide protection against ontological threats. More broadly, the entire traditional Navajo cosmological framework is about perpetuating harmonious relationships with kin $\left(k^{\prime} e\right)$, both human and non-human, as a way of protecting an individual against ontological threats (like witches and skinwalkers). So, in building positive human relationships with those "kings" in Benin whom he felt had "a good spirit", Pastor Begay was actively neutralizing ontological threats through the time-worn Navajo technique of making kin. In this way, ontological threats he felt while in Benin filtered through interactions that were informed by his Navajo perspective, but mixed with and refracted through specific interactions with West Africans.

\section{Conclusions}

This paper has explored two concrete instances of spiritual warfare in contact, illustrating, in detail, how missionaries negotiate conversations between localities. Actors from Juja, Edmond, Save, and Shiprock made legible various ontologies of spiritual warfare that they brought with them and that they encountered, reframing them in the Pentecostal/charismatic missionary networks in which they were embedded and redeploying them to protect themselves and their loved ones. Begay's focus on reciprocal networks among missionaries promoted the continuous circulation and adaptation of ontologies about spiritual warfare and the shape it takes in particular locales. The fragmentation of the denominational networks in Durham's case illustrates that spiritual warfare resonates outside of denominationally controlled channels in similar ways for international missionaries. What becomes clear in all of this is the power of interconnected networks as a motivating factor in Pentecostal/charismatic engagement with spiritual warfare.

The way in which Begay and Durham engaged with ontologies of spiritual warfare through these networks also offers a path out of the debate between continuity and rupture. Here, we see clearly that individuals (and their communities) are not just waging spiritual warfare against Christian demons, or assigning unseen forces to the "traditional" realm, but they are reframing the unseen universe into blanket ontologies of good and evil. Matthew Durham and Eunice Menja did this when they invoked possession as a way to absolve Durham from the agency and guilt associated with alleged child molestation, reframing Durham and his embodied innocence as good, and "Luke" and his actions as evil. What resulted was an enlivened universe not strictly Kenyan or Oklahoman, yet also not exactly the product of either Bible-Belt non-denominational Christianity or PCEA theological mission.

Begay also read past local (and localized) nuances of threat and protection, assuming a universal demonic power associated with his overall unease, as well as a universal technique of recruiting good allies when waging spiritual war. His careful attention to cementing these alliances through material

(but perhaps particularly in Equatorial societies), the payment of bridewealth, for example, was a vital tool in composing and cementing social networks (Guyer and Belinga 1995). Relatedly, long-standing cultural practices throughout the continent treat exchange and affect as mutually constitutive. In some cases, gifting and reciprocal exchange can be understood not only to solidify, but to create, relationships de novo. In Madagascar, for example, young women claimed that "there was no such thing as fitiavina [love] without money", suggesting money was a central driver in relationships of emotional attachment and physical desire (Cole in Thomas and Cole 2009; see also Hunter 2010). The same can be seen in relations among the living and their ancestors; reciprocity is often a central tenet underpinning the relationship between ancestors and descendants. Among the Luo in Kenya, for example, the virtue of "entrustment" guides how they conceive of relations between the living and their spirits and divinity (Shipton 2007). 
goods calls our attention to their importance, as well as the way in which our attention to "ontologies" (in debates about continuity versus rupture) may not be as important as attention to "strategies". Crucially, both of these case studies emphasize how fluid and malleable ideas about good and evil become as they circulate through known networks.

Finally, it becomes clear through these case studies that focusing on localized instances of contact can completely upend our assumptions about the flows of Christian missionary ideas and ontologies from North to South or core to periphery. As studies cited above have shown for earlier historical periods, there is no standard path of movement in these two cases, no set directionality of intellectual flow. Rather, there is a circulation and a mutual reinforcement of ideas as they move around the globe through networks of people. These on-going conversations between localities, permissible because of technology, constant travel, affective ties, and intellectual engagement, reframe our understanding of conversion and of the power (and future) of missionization.

Author Contributions: Conceptualization, A.P. and K.M.; Formal analysis, A.P. and K.M.; Investigation, A.P. and K.M.; Writing - original draft, A.P. and K.M.; Writing-review \& editing, A.P. and K.M. All authors have read and agreed to the published version of the manuscript.

Funding: Prichard's research was funded by the University of Oklahoma Foundation and an Arts and Humanities Faculty Fellowship from the Research Council at the University of Oklahoma. Marshall's research was funded by the Dolores Zohrab Liebmann Fund and a University of Oklahoma Junior Faculty Fellowship.

Acknowledgments: Andreana Prichard would like to acknowledge the numerous anonymous members of the evangelical community based in Oklahoma City and Edmond, Oklahoma, conversations with whom contributed to her understanding of the networks in which Durham, Menja, and their co-missionaries traveled. Conversations with several students and missionaries also contributed to this understanding. Theo Schlecht's impending arrival and early weeks of life spurred the completion of this article. Kim Marshall would like to acknowledge the support of Pastor Wallace Begay, his family, and his church community in facilitating this research. Marshall research was carried out under Navajo Nation Office of Historic Preservation permit \#C0614-E, Indiana University Human Subjects Research Review Board protocols \#06-11039 and \#07-12188, and the University of Oklahoma Institutional Review Board protocol \#0560.

Conflicts of Interest: The authors declare no conflict of interest.

\section{References}

Amster, Matthew H. 2009. Portable Potency: Christianity, Mobility and Spiritual Landscapes among the Kelabit. Anthropological Forum 19: 307-22. [CrossRef]

Annis, Sheldon. 1987. God and Production in a Guatemalan Town. Austin: University of Texas Press.

Bastian, Jean Pierre. 1993. The Metamorphosis of Latin American Protestant Groups: A Sociohistorical Perspective. Latin American Research Review 28: 33-61.

Blumhofer, Edith. 1993. Aimee Semple McPherson: Everybody's Sister. Grand Rapids: Eardmans.

Bowen, Kurt Derek. 1996. Evangelism and Apostasy: The Evolution and Impact of Evangelicals in Modern Mexico. In McGill-Queen's Studies in the History of Religion, 23. Montréal and Buffalo: McGill-Queen's University Press.

Butler, Melvin. 2019. Island Gospel: Pentecostal Music and Identity in Jamaica and the United States. Champaign: University of Illinois Press.

Casanova, José. 2001. Religion, The New Millennium, and Globalization. Sociology of Religion 62: $415-41$. [CrossRef]

Chesnut, R. Andrew. 1997. Born Again in Brazil: The Pentecostal Boom and the Pathogens of Poverty. New Brunswick: Rutgers University Press.

Chua, Liana. 2012. Conversion, Continuity, and Moral Dilemmas among Christian Bidayuhs in Malaysian Borneo. American Ethnologist 39: 511-26. [CrossRef]

Cole, Jennifer. 2009. Love, Money, and Economies of Intimacy in Tamatave, Madagascar. In Love in Africa. Edited by Jennifer Cole and Lynn M. Thomas. Chicago: University of Chicago Press, pp. 109-34.

Coleman, Simon. 2000. The Globalisation of Charismatic Christianity: Spreading the Gospel of Prosperity. Cambridge: Cambridge University Press.

Coleman, Simon, and Rosalind I. J. Hackett. 2015. Introduction: A New Field? In The Anthropology of Global Pentecostalism and Evangelicalism. Edited by Simon Coleman and Rosalind I. J. Hackett. New York: New York University Press, pp. 1-40. 
Comaroff, Jean, and John Comaroff. 1991. Of Revelation and Revolution, Volume 1: Christianity, Colonialism, and Consciousness in South Africa. Chicago: University of Chicago Press.

Comaroff, Jean, and John Comaroff. 1997. Of Revelation and Revolution, Volume 2: The Dialectics of Modernity on a South African Frontier. Chicago: University of Chicago Press.

Cox, Harvey. 1995. Fire from Heaven: The Rise of Pentecostal Spirituality and the Reshaping of Religion in the Twenty-First Century. Reading: Addison-Wesley.

Daswani, Girish. 2013. On Christianity and Ethics: Rupture as Ethical Practice in Ghanaian Pentecostalism. American Ethnologist 40: 467-79. [CrossRef]

Elisha, Omri. 2015. Personhood: Sin, Sociality, and the Unbuffered Self in US Evangelicalism. In The Anthropology of Global Pentecostalism and Evangelicalism. Edited by Simon Coleman and Rosalind I. J. Hackett. New York: New York University Press, pp. 41-56.

Engelke, Matthew. 2010. Past Pentecostalism: Notes on Rupture, Realignment, and Everyday Life in Pentecostal and African Independent Churches. Africa 80: 177-99. [CrossRef]

Frisbie, Charlotte J. 1987. Introduction: A Special Symposium Issue on Navajo Mortuary Practices and Beliefs. American Indian Quarterly 4: 303-8.

Garrard-Burnett, Virginia. 1998. Protestantism in Guatemala: Living in the New Jerusalem. Austin: University of Texas Press.

Garrity, John F. 2000. Jesus, Peyote, and the Holy People: Alcohol Abuse and the Ethos of Power in Navajo Healing. Medical Anthropology Quarterly 14: 521-42. [CrossRef]

Geschiere, Peter. 2017. Afterword: Academics, Pentecostals, and Witches: The Struggle for Clarity and the Power of the Murky. In Pentecostalism and Witchcraft: Spiritual Warfare in Africa and Melanesia. Edited by Knut Rio, Michelle MacCarthy and Ruy Blanes. London: Palgrave Macmillan, pp. 281-90.

Gifford, Paul. 2009. Christianity, Politics, and Public Life in Kenya. Oxford: Oxford University Press.

Gill, Sam D. 1987. Native American Religious Action: A Performance Approach to Religion. Columbia: University of South Carolina Press.

Guyer, Jane, and Samuel Belinga. 1995. Wealth in People as Wealth in Knowledge: Accumulation and Composition in Equatorial Africa. Journal of African History 36: 91-120. [CrossRef]

Hackett, Rosalind I. J. 1998. Charismatic/Pentecostal Appropriation of Media Technologies in Nigeria and Ghana. Journal of Religion in Africa 28: 258-77. [CrossRef]

Harris, Olivia. 2006. The Eternal Return of Conversion: Christianity as Contested Domain in Highland Bolivia. In The Anthropology of Christianity. Edited by Fenella Cannell. Durham: Duke University Press, pp. 51-76.

Helgen, Erika. 2020. Religious Conflict in Brazil: Protestants, Catholics, and the Rise of Religious Pluralism in the Early Twentieth Century. New Haven: Yale University Press.

Hollenweger, Walter J. 1997. Pentecostalism: Origins and Development Worldwide. Peabody: Hendrickson.

Hunter, Mark. 2010. Love in the Time of AIDS: Inequality, Gender, and Rights in South Africa. Bloomington: Indiana University Press.

Ingalls, Monique, and Amos Yong, eds. 2015. The Spirit of Praise: Music and Worship in Global Pentecostal-Charismatic Christianity. University Park: Penn State University Press.

Jorgensen, Dan. 2014. Mining Narratives and Multiple Geographies in Papua New Guinea: OK Tedi, the Emerald Cave, and Lost Tribes. Journal de la Société des Océanistes 138: 23-36. [CrossRef]

Joyce, Kathryn. 2017. The Rise of Biblical Counseling. Pacific Standard, June 14.

Kamsteeg, Frans. 1998. Prophetic Pentecostalism in Chile: A Case Study on Religion and Development Policy. Lanham: Scarecrow.

Kiernan, Jim. 1992. The Herder and the Rustler: Deciphering the Affinity between Zulu Diviner and Zionist Prophet. African Studies 51: 231-42. [CrossRef]

Kodesh, Neil. 2008. Networks of Knowledge: Clanship and Collective Well-Being in Buganda. Journal of African History 49: 197-216. [CrossRef]

Krause, Kristine. 2015. Orientations: Moral Geographies in Transnational Ghanaian Pentecostal Networks. In The Anthropology of Global Pentecostalism and Evangelicalism. Edited by Simon Coleman and Rosalind I. J. Hackett. New York: New York University Press, pp. 75-94.

Lampe, Frederick P. 2010. The Anthropology of Christianity: Context, Contestation, Rupture, and Continuity. Reviews in Anthropology 39: 66-88. [CrossRef] 
Landau, Paul. 1999. 'Religion' and Christian Conversion in African History: A New Model. Journal of Religious History 23: 8-30. [CrossRef]

Landau, Paul. 2000. Hegemony and History in Jean and John L. Comaroff's 'Of Revelation and Revolution.' Africa 70: 501-19.

Larson, Pier M. 1997. 'Capacities and Modes of Thinking': Intellectual Engagements and Subaltern Hegemony in the Early History of Malagasy Christianity. American Historical Review 102: 136-38. [CrossRef]

Laugrand, Frédéric B., and Jarich G. Oosten. 2010. Inuit Shamanism and Christianity: Transitions and Transformations in the Twentieth Century. Montreal: McGill-Queen's University Press.

Lee, Lloyd. 2014. Introduction. In Diné Perspectives: Revitalizing and Reclaiming Navajo Thought. Edited by Lloyd L. Lee. Tucson: University of Arizona Press, pp. 3-13.

Lehmann, David. 2001. Charisma and Possession in Africa and Brazil. Theory, Culture E Society 18: 45-74.

Lindhardt, Martin. 2015. Mediating Money: Materiality and Spiritual Warfare in Tanzanian Charismatic Christianity. In The Anthropology of Global Pentecostalism and Evangelicalism. Edited by Simon Coleman and Rosalind I. J. Hackett. New York: New York University Press, pp. 147-60.

Macdonald, Fraser. 2015. Lucifer is Behind Me: The Diabolisation of Oksapmin Witchcraft as Negative Cosmological Integration. Asia Pacific Journal of Anthropology 16: 464-80. [CrossRef]

Manning, Frank E. 1980. Pentecostalism: Christianity and Reputation. In Perspectives on Pentecostalism: Case Studies from the Caribbean and Latin America. Edited by Stephen D. Glazier. Lanham: University Press of America, pp. 177-87.

Marshall, Kimberly Jenkins. 2015. Non-Human Agency and Experiential Faith among Diné Oodlání, "Navajo Believers". Anthropologica 57: 397-409.

Marshall, Kimberly Jenkins. 2016. Upward, Not Sunwise: Resonant Rupture in Navajo Neo-Pentecostalism. Lincoln: University of Nebraska Press.

Marshall, Ruth. 2009. Political Spiritualities: The Pentecostal Revolution in Nigeria. Chicago: University of Chicago Press.

Marshall, Ruth. 2016. Destroying Arguments and Captivating Thoughts: Spiritual Warfare Prayer as Global Praxis. Journal of Religious and Political Practice 2: 92-113. [CrossRef]

Martin, David. 1990. Tongues of Fire: The Explosion of Protestantism in Latin America. Cambridge: Blackwell Press.

Matory, J. Lorand. 2005. Black Atlantic Religion. Princeton: Princeton University Press.

McMinn, Mark R., Ryan C. Staley, Kurt C. Webb, and Winston Seegobin. 2010. Just What is Christian Counseling Anyway? Professional Psychology: Research and Practice 41: 391-97. [CrossRef]

Meyer, Birgit. 1999. Translating the Devil: Religion and Modernity Among the Ewe in Ghana. Edinburgh: Edinburgh University Press for the International African Institute.

Meyer, Birgit. 2004. 'Praise the Lord': Popular Cinema and Pentecostalite Style in Ghana's New Public Sphere. American Ethnologist 31: 92-110. [CrossRef]

Miller, Ivor. 2012. Voice of the Leopard: African Secret Societies and Cuba. Oxford: University of Mississippi Press.

O'Neill, Kevin. 2015. Politics of Prayer: Christianity and the Decriminalization of Cocaine in Guatemala. In The Anthropology of Global Pentecostalism and Evangelicalism. Edited by Simon Coleman and Rosalind I. J. Hackett. New York: New York University Press, pp. 214-27.

Obadare, Ebenezer. 2018. Pentecostal Republic: Religion and the Struggle for State Power in Nigeria. Chicago: University of Chicago Press.

Ono, Akiko. 2012. You Gotta Throw Away Culture Once You Become Christian: How 'Culture' is Redefined among Aboriginal Pentecostal Christians in Rural New South Wales. Oceania 82: 74-85. [CrossRef]

Prichard, Andreana. 2017. Sisters in Spirit: Christianity, Affect, and Community Building in East Africa, 1860-1970. East Lansing: Michigan State University Press.

Pype, Katrien. 2017. Branhamist Kindoki: Ethnographic Notes on Connectivity, Technology, and Urban Witchcraft in Contemporary Kinshasa. In Pentecostalism and Witchcraft: Spiritual Warfare in Africa and Melanesia. Edited by Kunt Rio, Michaelle MacCarthy and Ruy Blanes. London: Palgrave MacMillan, pp. 115-44.

Reichard, Gladys. 1949. The Navaho and Christianity. American Anthropologist 51: 66-71. [CrossRef]

Rio, Knut, Michelle MacCarthy, and Ruy Blanes. 2017. Introduction to Pentecostal Witchcraft and Spiritual Politics in Africa and Melanesia. In Pentecostalism and Witchcraft: Spiritual Warfare in Africa and Melanesia. Edited by Knut Rio, Michelle MacCarthy and Ruy Blanes. London: Palgrave Macmillan, pp. 1-36. 
Robbins, Joel. 2003. On the Paradoxes of Global Pentecostalism and the Perils of Continuity Thinking. Religion 33: 221-31. [CrossRef]

Robbins, Joel. 2004. The Globalization of Pentecostal and Charismatic Christianity. Annual Review of Anthropology 33: 117-43. [CrossRef]

Shipton, Parker. 2007. The Nature of Entrustment: Intimacy, Exchange, and the Sacred in Africa. New Haven: Yale University Press.

Stoll, David. 1990. Is Latin America Turning Protestant?: The Politics of Evangelical Growth. Berkeley: University of California Press.

Stritecky, Jolene M. 2001. Israel, America, and the Ancestors: Narratives of Spiritual Warfare in a Pentecostal Denomination in Soloman Islands. Journal of Ritual Studies 15: 62-78.

Sweet, James. 2011. Domingos Alvares, African Healing, and the Intellectual History of the Atlantic World. Chapel Hill: University of North Carolina Press.

Synan, Vinson. 1997. The Holiness-Pentecostal Tradition: Charismatic Movements in the Twentieth Century. Grand Rapids: Eardmans.

Thornton, John K. 1998. The Kongolese Saint Anthony Dona Beatriz Kimpa Vita and the Antonian Movement, 1684-1706. Cambridge: Cambridge University Press.

Weaver, John. 2011. Unpardonable Sins: The Mentally Ill and Evangelicalism in America. The Journal of Religion and Popular Culture 23: 65-81. [CrossRef]

(C) 2020 by the authors. Licensee MDPI, Basel, Switzerland. This article is an open access article distributed under the terms and conditions of the Creative Commons Attribution (CC BY) license (http://creativecommons.org/licenses/by/4.0/). 